\title{
FRÁGEIS MULHERES-FERAS: CICATRIZES DA VIDA NA ALMA FEMININA
}

\author{
Roselene Berbigeier Feil \\ (Universidade Federal do Rio Grande do Sul)
}

\section{RESUMO}

Às personagens femininas Mia Couto delega uma missão: fazer o percurso, sofrido ou suave, entre o mundo do sonho e o da realidade, adiantando-lhes que em ambos os mundos as dores da alma e do corpo deixarão indeléveis cicatrizes. Revelações sobre o comportamento feminino, a submissão em relação ao poder masculino e a autoafirmação em momentos difíceis encontram no mundo do sonho a satisfação dos desejos mais românticos e das mais femininas necessidades. Entre os percalços do cotidiano e a esperança de dias melhores, as mulheres de Mia Couto transitam do possível ao impossível, da fragilidade à força absoluta. Na maioria dos romances do autor moçambicano, dentre os quais O outro pé da sereia (2006), Terra sonâmbula (2007) e A confissão da leoa (2012), são encontradas mulheres modelo de superação, mulheres que fazem da vida uma travessia em busca de conforto espiritual, uma vez que o afetivo e o material lhes parecem inalcançáveis. Pretende-se neste ensaio um encontro bastante especial com Constança e Mwadia Malunga, Farida, Virgínia Pinto, Hanifa Assulua, Naftalinda Makwala e Mariamar Mpepe que terão a oportunidade de relatar uma parte de suas ricas, e dolorosas, experiências de vida.

PALAVRAS-CHAVE: personagem, feminina, Mia Couto.

\section{ABSTRACT}

On female characters Mia Couto delegates a mission: fly the route, or suffered mild, between the dream world and reality, adding them in both worlds pains of soul and body will leave indelible scars. Revelations about female behavior, submission in relation to male power and self-assertion in tough times are in the dream world of the satisfaction of desires more romantic and more feminine needs. Among the mishaps of everyday life and the hope of better days, women of Mia Couto transiting the impossible of possible, the absolute strength of weakness. In most novels the author Mozambique, among them The other foot mermaid (2006), Earth sleepwalker (2007) and 
Confession Lioness (2012) found women are overcoming model, women who make life a journey in search of spiritual comfort, since the emotional and material they seem unattainable. The aim is to test a meeting very particular with Constance and Mwadia Malunga, Farida, Virgínia Pinto, Hanifa Assulua, Naftalinda Makwala and Mariamar Mpepe who will have the opportunity to share a part of their rich and painful life experiences.

KEYWORDS: character, female, Mia Couto.

Sábio é o pirilampo que usa o escuro para se acender.

Provérbio de Kulumani

Se na cultura ocidental as mulheres ainda encontram dificuldades para se expressarem, para fazerem valer os seus direitos, o que dizer de povos que mantêm fortes laços com as tradições, culturas nas quais, geralmente, os homens são o centro das atenções e às mulheres relega-se apenas o papel de gerar os filhos e de fazê-los crescer quando possível, isto é, quando a crueza da vida não os rouba ainda no ventre ou em tenra idade, as mulheres têm por função cuidar da subsistência, cabe a elas amparar material e sentimentalmente todos os que lhes cercam. Enfrentam tarefas árduas, cotidianas, sem um tempo para acabar, sem o legítimo privilégio de serem apenas mulheres, sem se dedicarem a si mesmas e aos prazeres femininos. "Pobres mulheres", dizem alguns, mas mal sabem a força que elas têm, invejáveis fortalezas.

Os romances da literatura moçambicana de Mia Couto são celeiros que guardam mulheres guerreiras, algumas delas apenas ruínas de fortalezas construídas com matéria ímpar: às vezes lágrimas, outras, terra, mas sempre forjadas a pesadelos e a sonhos. Sonhos que transcendem o espaço do sonhado e firmam-se como alicerces reais para a continuidade da vida, pois, como o próprio autor compreende, "ficção e realidade são as gémeas e convertíveis filhas da vida" (COUTO, 1991, p. 77), num círculo em que o viver e o sonhar são lados da mesma moeda, em que acreditar na força dos sonhos salva a própria história.

Nas palavras de muitas delas, lidas como metáforas de mulheres reais, são traduzidas as experiências de momentos traumáticos e oníricos, de momentos que trazem, na poética das dores sofridas, exemplos que fazem perceber o quanto a mulher ocidental já progrediu e o quanto falta às outras ainda percorrer rumo à melhoria de suas vidas. Nada mais produtivo e enriquecedor para a compreensão de suas realidades do que ouvir as próprias personagens, enquanto expoentes de mulheres concretas, falando sobre suas experiências. Nesse sentido, é a elas que se dá a palavra, fugindo de quaisquer teorizações ou filosofias vazias de significado para quem sofre com tantos problemas do dia a dia, promovendo uma interação subjetiva entre quem as lê e quem elas representam: mulheres sofredoras 
que têm como ponto comum a alma, o sangue e o desejo de uma felicidade plena. Em suas falas, é possível observar um ritmo calejado, uma respiração compassada entremeada por suspiros que rementem a tempos e a situações imemoriais, uma dicção sofrida e lastimosa que, em algum sentido, é capaz de alcançar a sensibilidade além do sexo; para compreendê-las não é preciso ser mulher, é preciso sentir. O que faz lembrar Lúcia Castelo Branco (1991) ao ponderar que o feminino e o masculino transcendem as categorias sexuais e fisiológicas - independentemente do sexo biológico, as configurações psíquicas são as que devem prevalecer.

Parece-nos prudente alertar que, ao longo deste ensaio, será percebido um tom fortemente descritivo, bem menos reflexivo ou subjetivista do que se costuma observar na maioria dos ensaios críticos sobre literatura; isso porque não se pode, priorizando a voz das mulheres aqui apresentadas, exigir que elas reflitam, que interroguem, que procurem caminhos quando a elas não foi ensinado senão ver o mundo que as cerca sem indagar os porquês de muitas situações. Nesse intuito e dando voz às mulheres de Mia Couto, ouve-se primeiro à Constança Malunga, o símbolo dos maus tratos em O outro pé da sereia (2006).

Constança Malunga nutre-se das próprias mágoas. A comida serve-lhe de consolo aos tantos desamores, ao abandono das filhas e à resignação de ser uma mulher interdita aos prazeres da vida, "demasiado esposa para ser mulher" (COUTO, 2006, p. 178). Constança, num rito de obrigação, recebeu por herança "ser a última a deitar-se e não dormir com medo de não ser a primeira a despertar" (COUTO, 2006, p. 171). Teve por única vocação a missão dada às descendentes de Eva, parir filhos, uma missão que pouco lhe agradara, tanto que comemora com festa o tempo da menopausa, “- Esta festa é para dar Graça a Deus. Porque, a partir de hoje, eu sequei [...] É verdade, [...] em mim já mirrou todo o pólen. Sou uma mulher seca. Se alguma vez mais eu sangrar não será por motivos de mulher" (COUTO, 2006, p. 171). Mwadia Malunga, a única filha com quem tem algum contato, não entende a satisfação da mãe em não poder mais gerar vida: “- Mas a mãe não gostou de nos ter? - Nunca vos tive. Vocês é que me tiveram a mim, me sugaram não só os peitos, mas chuparam-me o alento de viver" (COUTO, 2006, p. 171). No entanto, a velha reconhece, num sinal de íntima incoerência, que as filhas lhe deram a única vida que possuiu. Parece certa de ser esta a única vida possível diante de um destino traçado com marcas vindas de outros aléns. Constança lastimava a ausência delas, não se sabe para onde e quando partiram, mas já não as vê há muito tempo, tanto que a saudade já conseguiu aplacar todas as demais dores, restando-lhe agora pequenas memórias compartilhadas com Mwadia, enquanto mistura à conversa desabafos sobre sua condição de esposa reprimida, pergunta à filha:

- Lembra-se do tempo em que eu passava tardes e tardes costurando? 
- Lembro-me mãe. Eram tantas filhas, tantas roupas!

- A maior parte das vezes, eu só fingia que costurava.

- Fingia? Fingia para quê?

Os homens não gostam que as mulheres pensem em silêncio. Nascem-lhes nervosas suspeitas.

- Enquanto ia costurando, o seu pai não imaginava que eu estava pensando. Minha cabeça viajava por todo lado.

Nesses escassos momentos, Constança era mulher sem ter que pedir licença, existindo sem ter que pedir perdão (COUTO, 2006, p. 78-79).

A grande benção que recebera durante a vida não passou de uma mesa posta com alimentos para todos. Para ela, o verdadeiro milagre era poder alimentar a família, algo que se lhe assemelhava aos mais doces sonhos possíveis de acontecer. Às mulheres Malunga desde cedo era ensinado que "nascemos e choramos. A nossa língua materna não é a palavra. $\mathrm{O}$ choro é nosso primeiro idioma. O único" (COUTO, 2006, p. 172).

Mwadia se dá conta, com insistência, que suas teimosas reminiscências e medos são um painel da triste situação de Antigamente e de Vila Longe, vilarejos onde transcorrem os fatos narrados na trama de $O$ outro pé da sereia (2006), muitos deles através da percepção dela mesma. Mwadia (canoa) é um elemento de travessia entre os espaços fluidos que oscilam em ritmos alucinatórios mesclando a dúvida e a certeza, o delírio e a lucidez - com um ontem e um hoje sem qualquer indicação de um amanhã. $O$ narrador explica que a vida de Mwadia era feita de contrassensos, que "ela era do mato e nascera em casa de cimento; era preta e tinha um padrasto indiano; era bela e se casara com um marido tonto; era mulher e seca sem descendência" (COUTO, 2006, p. 69). Mwadia consegue, no transcurso de sua jornada, conhecer o passado e o futuro, dialogar com a realidade presente que lhe atravessa e entender que bom remédio contra tudo que percebe seria a morte. Ao marido Zero Madzero exige que cumpra uma antiga promessa:

- Há quantos anos você anda a prometer que vai me tirar dessa porcaria de vida?

- Mas Mwadia, você não desiste dessa ideia?

- Eu já não tenho motivo de viver, Zero. E você me prometeu que me matava de boa maneira.

- Eu ainda estou a pensar numa maneira.

- Ainda estou a pensar, ainda estou a pensar... pois pense rápido (COUTO, 2006, p. 26).

Por meio desse questionamento, Mwadia leva o leitor a se perguntar: o que faz alguém desejar morrer, seriam os traumas, a saudade, 
o desalento e a desesperança algo suficiente para esse querer insistente? Mwadia é a sinopse de tantos sentimentos, de muitas dores e da criação de mentiras salvadoras, e faz da ilusão de cada dia uma verdade eterna. Era uma dessas mulheres que "já nem carecia de morrer" (COUTO, 2006, p. 26), porque, "longe da família, sem filhos, sem chuva, naquele canto do mundo, Mwadia não era nem a árvore nem a raiz [...]. Ela era um arbusto definhado e seco. Toda a morte tem o seu quê de suicídio. Mwadia, porém, já não se considerava vivente" (COUTO, 2006, p. 26). Ainda que desejasse a morte, sabia que os mortos nunca desapareciam de todo, mas se transferiam para a memória daqueles que ficam - a servidão humana vai além da vida e alcança a morte.

Em Terra sonâmbula (2007), Farida é uma mulher enigmática narrada pelas memórias de Kindzu em seus cadernos. Para o velho Tuahir que ouve os relatos encontrados e lidos por Muidinga, Farida tem um diferencial em relação a todas as outras: "há mulheres que são chuva, outras cacimbo. Essa tal Farida deve ser uma que vale a pena a gente se despentear com ela" (COUTO, 2007, p. 64). Contudo, apesar do encantos identificados por Tuahir, os traumas de Farida vêm de longa data: nasceu gêmea com uma irmã e, de certo modo, carregava a culpa por sua morte. Conforme a tradição de sua gente, uma das duas precisaria morrer para que a terra não sofresse os castigos do céu - em algum sentido, isso significa a interdição do céu às mulheres: ser mulher e ser gêmea, um duplo castigo adquirido ao nascer. Poucos dias após o nascimento, deixaram que a irmã morresse de fome em cumprimento às determinações ancestrais:

fizeram isso por bondade: para aliviar a maldição. Enterraram a menina no pequeno bosque sagrado onde dormem as crianças falecidas. Meteram-lhe numa panela de barro quebrada. Foi semeada sem quase nenhuma terra lhe cobrir. Destinaram-lhe um lugar perto do rio, onde o chão nunca seca. Assim as nuvens lembrar-se-iam sempre da obrigação de molhar a terra (COUTO, 2007, p. 70).

À mãe de Farida não foi permitido chorar sua dor; contra a força dos desígnios pouco há a ser feito, chorar é visto como um sinal de insatisfação, e essas lágrimas, que extirpariam a dor, poderiam vir a questionar a validade da eterna submissão das mulheres, poderiam ser um indício de indignação frente à dor que sofrem séculos e séculos afora. Entretanto, apesar do silêncio e das lágrimas sufocadas ainda em estado gestacional, a condenação dada a elas, pela aldeia, não foi anulada com os rituais. Nenhum esforço, nada parecia suficiente. Mesmo após as cerimônias o castigo a ambas não cessou: mãe e filha foram exiladas pelos seus em sua própria terra, e tal exílio não era apenas espacial e físico, mas emocional também. Numa grande fogueira queimaram a palhoça em que viviam com todos os seus pertences: "depois das cerimónias, mandaram que a mãe saísse da aldeia. Junto com a filha foram morar num mato próximo, de verdes desleixados. 
Ali viveram sem nunca receber visitas: vinham os da família mas ficavam longe, escondidos. Receavam o contágio" (COUTO, 2007. p. 71). Na infância, a menina Farida acreditava que a irmã tivesse ido viver com a avó, mas era apenas uma história contada pela mãe para que a culpa não lhe pesasse tanto.. Farida desde sempre parece destinada à solidão, mesmo sendo

filha do Céu, estava condenada a não poder nunca olhar o arco-íris. Não lhe apresentaram à lua como fazem com todos os nascidos da sua terra. Cumpria um castigo ditado pelos milénios: era filha-gémea, tinha nascido de uma morte. Na crença da sua gente, nascimento de gémeos é sinal de grande desgraça (COUTO, 2007, p. 70).

A orfandade emocional é a certidão de nascimento de Farida, que cresceu isolada, impedida de gestos de afeto, acariciada apenas por si mesma. Sua vida é espera: esperava pela felicidade, esperava pela mãe que também fora dada em ritual de purificação à aldeia, esperava por explicações que lhe traduzissem o passado, esperava pelo filho nascido do assédio sexual praticado por aquele que pensava ser a possibilidade de um segundo pai. Gaspar/Muidinga é o filho que fora deixado aos cuidados da Missão, um filho que lhe "nasceu sem que ela nascesse mãe. Em nenhum momento [...] notou alguma vontade de lhe dar cuidados. [...] entregou a criança como se fosse uma encomenda de ninguém, um lapso da vida. [...] Se queria ver o filho? Não sabia, lhe custava falar o assunto" (COUTO, 2007, p. 79). O fato de ser e não ser mãe ao mesmo tempo era sua grande dor, contra a qual lutava recorrendo ao mundo paralelo, escondendo-se de si mesma sempre que fosse possível. Farida, tal como Mwadia, carrega traços da duplicidade, nascera dupla: era mãe sem querer ser, sentia-se a causa de um homicídio sem tê-lo praticado, fora expulsa da aldeia sem que esta tenha saído de si, procurava um amor sem saber do que se tratava. Farida e Mwadia são, em verdade, as mulheres encontráveis em todo o DNA feminino, seria demasiado exagero pensar que algumas tendências são de fato biológicas? Não se pode ignorar que, além da força extremada de certas mulheres, há uma trama comum, certo bordado com os mesmo fios e cores fazem da existência feminina um esboço inacabado, gracioso e desafiador do qual a literatura tem a capacidade de absorver os melhores elementos.

A oportunidade que o destino lhe deu para aproximar-se de alguma acolhida foi ter sido recebida na casa de Virgínia Pinto, uma esperança de segunda mãe, esposa daquele que seria, no futuro, seu abusador. No entanto, essa acolhida não dura muito tempo, apesar dos laços de amizade entre ambas, Virgínia sente-se obrigada a proporcionar à Farida outro modo de vida: a menina é entregue à Missão para ficar protegida do assédio de Romão Pinto e ter chance de uma vida diferente, talvez um futuro. Num acordo com os padres, Farida é aceita, se percebe órfã pela segunda vez, nesse momento de dor: 
Virgínia lhe deu as mãos, os dedos das duas se ameijoaram. Os corpos se despediam, sem competência para $o$ adeus.

- Vou continuar a escrever-lhe, mamã.

- Não é preciso, filha. Já não preciso.

E afastou-se, suas costas mirrando no escuro. Naquele momento, começava a segunda orfandade de Farida (COUTO, 2007, p. 76).

Com tantos traumas, desde cedo Farida "ingressara no obscuro mundo dos sobreviventes" (COUTO, 2007, p. 73), que mais lhe faltava acontecer? Simplesmente "lhe faltava o acontecer da vida, a quentura do mundo onde nascera. Aquele lugar (a missão) lhe deixava um frio interior. Afinal, todos queremos no peito o nó de um outro peito, o devolver da metade que perdemos ao nascer" (COUTO, 2007. p. 75-76). Numa tentativa de reencontrar aconchego, Farida deixa a Missão e retorna à casa de Virgínia, ainda que soubesse que foi naquele lugar "que, pela primeira vez, sentiu os olhos de um homem salivando. Romão Pinto lhe perseguia, suas mãos não paravam de lhe procurar. Às vezes, de noite, espreitava pela janela enquanto ela tomava banho. Farida estava cercada, indefesa" (COUTO, 2007, p. 74).

Virgínia era generosa, cuidou de Farida quando a aldeia em que vivera a abandonou de vez. Tomando consciência de que sua terra já estava cansada dela e dos problemas que seu nascimento trouxera, Farida lançou-se na estrada a caminho de não se sabe o quê, com quase nada de seu, "andou, andou, andou. Passou-se uma noite, uma manhã” (COUTO, 2007, p. 73), até encontrar apoio na solitária Virgínia, uma mulher proibida de viver:

[...] vivia vagarosa como uma lágrima. Romão a guardava em estado de matéria, com garantia de que ela existisse simples de lembrar.

- Estás proibida!

O marido lhe gritava com insistência as interdições: ler, ouvir rádio, cantar. Tudo porque ela insistia no desejo de regressar a Portugal. Era a sua única vontade, o breve círculo do seu sonhar (COUTO, 2007, p. 74).

A submissão de Virgínia, as diversas interdições a que estava suscetível a impediam de posicionar-se em relação ao assédio de Romão, um homem duro, desapegado de todo amor. Como único socorro possível, distancia-se da menina levando-a à Missão. Virgínia sabia que Romão rondava o leito de Farida, e esta, sem forças para reagir, dá-se conta de que

os passos dele cercavam-lhe o medo, enquanto ia esquentando suas brasas. Em silêncio, rezou com desespero. Colocou tanta fé nesse socorro que perdeu o receio do que pudesse suceder. Romão se sentou na cama, seus braços procuraram no escuro. Quan- 
do seus dedos roçaram o rosto da menina ele sentiu o molhado de caladas lágrimas. Essa tristeza ainda mais lhe afiou os apetites. Foi envolvendo Farida, cada avanço dele a doidoendo. Joelhos no peito, ela se pequeninava. Lá fora, a meiguice da lua não fazia suspeitar quanto ódio fermentava naquele quarto. Os anjos demoravam, Romão ganhava vantagem. Na aflição ela se perguntava: e afinal Deus? Por que se demora tanto? (COUTO, 2007, p. 78)

Farida é uma mulher que viu e viveu muita coisa, o delírio passou a ser seu amigo mais fiel; cada vez que sofria de suas estranhas febres, cada vez que a vida a obrigava a desacreditar da própria existência, tinha um único recurso, "contava sua estória, fiava e desfiava lembranças" (COUTO, 2007, p. 92) que se traduziam em "novas verdades a uma vida feita de mentiras” (COUTO, 2007. p. 75), tal como fora também para Virgínia.

Farida vivia, como não podia deixar de ser diante das circunstâncias, de ilusões, cultivava em si sonhos que só mulheres são capazes de cultivar, “- É o tempo da gente ser cada um. Só isso, [...] Eu quero sair, continuar viva" (COUTO, 2007, p. 97). O barco encalhado que lhe serviu de refúgio durante anos não comportava a dimensão do seu desejo de seguir adiante, mas ela, contudo, recusava-se a abandoná-lo dizendo "aqui [...] é o meu ninho. E depois, tenho a certeza, me hão-de vir buscar. Um barco desse tamanho não pode ser esquecido. Os donos virão rebocar esta carcaça, eu irei junto. Para longe, muito longe" (COUTO, 2007. p. 97). Farida era o desejo de ficar e de partir, de viver além das possibilidades de seu mundo sem despender-se totalmente dele. O exílio na infância a traumatizou; ao ser obrigada a partir por várias vezes dá a entender que ela tenha absorvido a vontade de desbravar, de procurar um lugar que finalmente seja seu. Os lugares permitidos à Farida, entretanto, são sempre internos, longe do mundo, dos homens - dentro de si mesma num espaço de confrontação com seus fantasmas interiores.

Em A confissão da leoa (2012), o mais recente romance de Mia Couto, expõem-se os dilemas de diversas mulheres: Hanifa Assulua e sua filha Mariamar costuram o destino das personagens femininas em meio a histórias de estupro, incesto, caridade perversa, traição e opressão das mais variadas formas. Logo de início, Hanifa, com a perda da filha Silência, devorada pelos leões, se pergunta o que fazer com o que lhe resta da vida, um fardo estranho em relação ao qual não mantinha nenhuma expectativa de entendimento. A vida construiu para Hanifa, nas cercanias da casa, um cemitério todo seu, com lápides familiares, jazigos onde enterrara suas filhas Uminha e Igualita. Tendo consciência de que os túmulos são inevitáveis e que continuarão a brotar da terra, ao marido Genito Serafim Mpepe indaga: “- E o que fazemos agora, ntwangu? [...] - O que fazemos agora? Ora, agora... agora, vivemos, mulher. - Eu já não sei viver, ntwangu” (COUTO, 2012, p. 15-16). Guardada na própria sombra, Hanifa enfrentou as muitas tragédias de Kulumani, para ela a vida nunca fora fácil, jamais fora dona 
de sua vontade e de seu destino. Tinha apenas uma certeza a transmitir à filha Mariamar, a de que "- Nós todas, mulheres, há muito que fomos enterradas. Seu pai me enterrou; sua avó, sua bisavó, todas foram sepultadas vivas" (COUTO, 2012, p. 43). As palavras de Hanifa têm poder; aos poucos Mariamar começa a entender a real condição de sua existência e admite que ela "tinha razão: talvez eu, sem saber, já estivesse enterrada. De tanto desconhecer o amor, eu estava sepultada" (COUTO, 2012, p. 44).

Ao que parece, cabe-lhes a resignação de esperar, sem que saibam exatamente o que é esperar, por que e pelo que se espera. A imperiosa ordem de viver soa-lhes como um contrassenso: qual a vida que se projeta num universo em que as esperanças desvanecem a cada nascer do dia? Viver seria castigo de algum antepassado ou a simples imposição do tempo aos habitantes de um cemitério cheio de vivos, povoado por casas decrépitas, "descoloridas, tristonhas, como que arrependidas de terem emergido do chão" (COUTO, 2012, p. 44). O certo é que a vida transcorria já sem vida e o tempo era uma espécie de barco em que navegava "gente que nunca foi gente" (COUTO, 2012, p. 45).

O tempo é um dos elementos marcantes na construção das narrativas dessas mulheres, um tempo que teima em ser apenas presente, o passado é carregado com todas as suas marcas até o agora e se tem a impressão de que se estenderá enquanto houver um futuro, se houver. Desvencilhar, esquecer e superar são verbos não conjugáveis. Na prática, resta o sobreviver como síntese de toda a vida - e em alguns casos, sobreviver deveria, ou poderia, ser substituído por "subviver" ou "sobviver" devido à penosa singularidade da condição feminina, especialmente ao se tomar consciência da realidade moçambicana que está para além da literatura. É preciso notar que as palavras, ainda que esforçadas, não dão conta de dimensionar o real estado das coisas, aliás, esse nem é o propósito da literatura.

Mariamar Mpepe é exemplo da manutenção de um passado no presente e da sua propagação no futuro. Suas lembranças, carregadas de subjetividade, são um dos recursos que a mantém viva. Mariamar ampara-se naquilo que teria sido a ela um gesto de amor, o único. Através da permanência desse fiapo de carinho consegue suportar as adversidades cotidianas. Apesar disso, nem tudo é positivo, ela aprisiona-se numa realidade imaginada e "desde então nunca mais tive sossego. Fugir de um amor é o modo mais total de lhe obedecer. Quanto mais senhora de mim, mas escrava desse amor. Não há, neste mundo, rio que me liberte dessa armadilha" (COUTO, 2012, p. 50). A carência de Mariamar sugere alguma poesia à sua vida "quem sabe o caçador me abraçaria e me ergueria pelos céus num estonteante voo?” (COUTO, 2012, p. 53). A jovem lembra-se com recorrência que seus sonhos dourados não passam de divagações infantis que a salvam e a entorpecem - imaginar: um doce paliativo a quem tem o desejo de ser amada -, pois para ela "não houve nem amor, nem homem, nem alma" (COUTO, 2012, p. 54). 
Mariamar resguarda-se da crueldade da vida que lhe é imposta refugiando-se na lembrança desse "amor fabulado e fabuloso", momento em que se sentiu gente, em que se viu defendida por alguém. Há precisos dezesseis anos, conhecera Arcanjo Baleiro, caçador que a salva do assédio de Maliqueto Próprio. Arcanjo passa a ser o motivo de sua vida, nunca deixou de esperá-lo como seu salvador. As dores de amor de Mariamar ganham dimensão de loucura, mas a razão daquela loucura sempre fora motivo para segredo: "Eu estava doente, sim. Mas essa doença era a única coisa que me protegia do meu passado" (COUTO, 2012, p. 86). Revela que, no tempo em que acontecera, a paixão não passava de uma súplica por vida nova, uma chance de ser levada de Kulumani, uma cidade-enferma que lhe impregnava a existência: "eu apenas pedia socorro, em silêncio rogava que ele [Arcanjo] me salvasse dessa doença” (COUTO, 2012, p. 87).

Mariamar sentia-se condenada a ser de um único lugar e a ter uma única existência: "eu era uma coisa e seria enterrada como um objeto na poeira de Kulumani” (COUTO, 2012, p. 121). Para fugir dessa condenação e impedir que outras mulheres a sofressem, Mariamar assume nas derradeiras páginas do livro que é a própria leoa e que já não sofre como houvera sofrido ao cometer os primeiros assassinatos. Sua real intenção tinha algo de nobre: evitar que nascessem novas crianças - por isso a opção por matar mulheres, pois via nisso o único meio de evitar que o rio recebesse em "suas margens os defuntos corpos de crianças" (COUTO, 2012, p. 240).

A nobreza de alma da personagem manifesta-se, ainda que de um modo cruel, ao fazer uma promessa: não descansaria enquanto não eliminasse "todas as remanescentes mulheres" (COUTO, 2012, p. 239), de modo a que "neste cansado mundo, restem apenas homens, um deserto de machos solitários. Sem mulheres, sem filhos, acabará assim a raça humana” (COUTO, 2012, p. 239). Isso porque, em sua concepção, naquilo que da vida conseguiu elaborar compreensivamente, pouco mantinha de raça "Humana” em sua essência. Ao tornar-se a vingativa leoa, já não era "demasiado pessoa" (COUTO, 2012, p. 240). Noutros tempos sofrera de uma doença por ela chamada de "consciência". $\mathrm{Na}$ atualidade, a vida deixava claro que "consciência" era um traje de conveniência e que alguma coisa haveria de fazer para "proteger" aquelas a quem amava. Ao assumir os assassinatos, investida de uma possessão anímica, entende que "já não há remorso. Porque, a bem ver, nunca cheguei a matar ninguém. Todas essas mulheres já estavam mortas. Não falavam, não pensavam, não amavam, não sonhavam. De que valia viverem se não podiam ser felizes?" (COUTO, 2012, p. 240). Reforça sua argumentação explicando os motivos que a levaram a matar:

Pela mesma razão, anos antes, matei as minhas pequenas irmãs. Fui eu que afoguei as gémeas. Todos pensam que foi um acidente no barco, mas fui eu que sabotei a embarcação e que a lancei vogando sobre as ondas do mar. Foi melhor que essas meninas nunca tivessem crescido. Porque elas só se sentiriam vivas na 
dor, no sangue, na lágrima. Até que, um dia, de joelhos, pediriam perdão aos seus carrascos. Como eu fiz, todos esses anos, com Genito Mpepe.

Fui eu que conduzi Silência até à boca da morte, naquela fatal madrugada. Ela era minha irmã, minha amiga. Mais do que isso, ela era a minha outra pessoa. Da parte dela, porém [...] sempre se apropriou dos meus sonhos [...]. Porque ela não tinha alma para, em si, inventar outra vida. Estava morta pelo medo. Por isso, quando terminou de viver já não houve falecimento. (COUTO, 2012, p. 240-241, grifos nossos)

A protagonista desse romance, no esplendor de sua controversa feminilidade, tem um súbito momento de satisfação pessoal. Logo no início do relato, dá ao leitor uma pista de sua íntima relação com a leoa, afirmando que há entre ambas uma harmonia, e sorri

com incontida vaidade. Todas acreditam que são leões machos que ameaçam a aldeia. Não são. É esta leoa, delicada e feminina como uma dançarina, majestosa e sublime como uma deusa, é esta leoa que tanto terror tem espalhado em todas as vizinhanças. Homens poderosos, guerreiros munidos de sofisticadas armas: todos se prostraram, escravos do medo, vencidos pela sua própria impotência. (COUTO, 2012, p. 55)

Filha de Hanifa, Mariamar enfrenta com a arma do sonho, assim como outras mulheres dos romances de Mia Couto, uma realidade marcada por diversas dores desde a infância. Traumatizada pelo abuso sexual praticado pelo pai Genito, com o qual a mãe Hanifa foi sempre conivente, era regida pelo que chama de "essas leis que nem Deus ensina nem o Homem explica” (COUTO, 2012, p. 26). Em conformidade com o seu tempo percebe que pouco se há de fazer. Tendo como exemplo a mãe, entende que "preferir não era um verbo feito para ela. Quem nunca aprendeu a querer como pode preferir?" (COUTO, 2012, p. 24)

A confissão da leoa é um romance muito rico em se tratando de personagens femininas. Naftalinda Makwala é uma surpresa. Por trás dos ares de Imperatriz da primeira-dama de Kulumani - "um lugar fechado, cercado pela geografia e atrofiado pelo medo" (COUTO, 2012, p. 21) -, se esconde um coração revoltado: mesmo sendo uma personagem com condição de vida privilegiada consegue indignar-se com a posição delegada às demais mulheres: “- Fingem que estão preocupados com os leões que nos tiram a vida. Eu, como mulher, pergunto: mas que vida há ainda para nos tirar? - Que conversa é essa esposa? - Sabe por que não deixam as mulheres falar? Porque elas já estão mortas" (COUTO, 2012, p. 115).

O inconformismo de Naftalinda a faz desafiar antigas tradições: mulheres nunca estiveram autorizadas a emitir opinião sobre quaisquer assuntos, muito menos são chamadas a ter voz em assuntos de gravidade, como a caçada aos leões que assombram Kulumani. Contudo, 
Inesperadamente, uma voz feminina se faz escutar, herética e imprevista [...] Surpresos os homens encaram a intrusa.

- Camarada primeira-dama, por favor, este é um encontro privado...

- Privado? Não vejo nada de privado, aqui. E não me olhem assim que não tenho medo. Sou como os leões que nos atacam: perdi o medo dos homens [...] Uma mulher foi violada e quase morta, nesta aldeia. E não foram os leões que o fizeram. Já não há lugar proibido para mim (COUTO, 2012, p. 114).

Naftalinda entende que os inimigos são outros, são aqueles que estão perplexos enquanto a ouvem falar, sua arrogância e desdém denotam a descrença nos ardis masculinos. A desconfiança da personagem segue a mesma tendência das mulheres de O outro pé da sereia (2006) e Terra sonâmbula (2007), obras nas quais a insatisfação com a vida proporcionada a elas pelos homens também é uma cicatriz que carregam na alma. O casamento é uma tortura que se acumula por décadas, que não cessa nem com a viuvez. No universo dessas mulheres, serem esposas traduz-se numa outra maneira de serem escravas. A viuvez chega apenas para acrescentar-lhes mais solidão à servidão. Num desabafo de Filipa ouve-se que "a gente ama alguém que desconhecemos, casa com quem conhece, vive com uma pessoa irreconhecível. Às vezes temos luas-de-mel, outras vezes, luas melosas. A maior parte do tempo, porém, são noites sem luar nenhum" (COUTO, 2006, p. 314).

As muitas histórias contadas pelas mulheres construídas por Mia Couto mantêm uma textura na voz que faz toda a diferença na configuração do texto, a poeticidade de alma dessas mulheres ressoa e interfere no ritmo de leitura: mostra paisagens bucólicas misturadas às sensações desconfortáveis. O assombro diante de um “feminino" tão sofrido, tão desgastado e devastado pela vida, não pode ser desconsiderado ou ignorado pelo leitor, ainda que este procure distanciar-se emocionalmente delas. De certa forma, as mulheres de Mia Couto representam ou tendem a representar personagens familiares, a trama que as enreda permite visualizar um contexto feminino atemporal e não pontuado por fronteiras geográficas. A simbiose entre todas as mulheres, reais e ficcionais, evidencia um lastro comum: a sensibilidade feminina perceptível no mínimo sinal da existência humana.

Os reflexos da violação de almas e de corpos, muitos deles através da submissão aos maridos e outros abusadores, e os reflexos das dores deixadas pelas décadas de sofrimentos vários são percebidos em outras mulheres da ficção do autor moçambicano. Como homenagem a elas é preciso destacar outras guerreiras. De boa parte de sua obra ao menos uma representante foi escolhida como símbolo daquilo de que se pretendeu falar neste ensaio: mulheres que se tornaram frágeis ou feras em decorrência das 
cicatrizes que a vida lhes impôs. De O último voo do flamingo (2005), não é possível esquecer-se de Temporina e de Hortênsia, mas é Ana Deusqueira quem tem grande importância desde o início da narrativa. A ela, a partir de sua profissão - prostituta -, cabe a função de identificar os restos mortais dos soldados da ONU explodidos durante a missão de Paz - Ana Deusqueira era "a mais conhecedora dos machos locais" (COUTO, 2005, p. 26). Em Antes de nascer o mundo, (2009) Marta, Noci e Dordalma são figuras singulares. A dor parece ter contemplado a última com uma dose aniquiladora. Castigada por sua beleza, das mulheres recebia a inveja e dos homens o desejo. O narrador afirma que lhe dói tratar o martírio de Dordalma, "de como ela perdeu a vida, depois de se ter perdido da vida" (COUTO, 2009, p. 242). Se a ele dói, certamente ao leitor também doerá saber que ela

foi arremessada no solo, entre babas e grunhidos, apetites de feras e raivas de bicho. E ela foi-se afundando na areia como se nada mais que o chão protegesse o seu frágil e trémulo corpo. Um por um, os homens serviram-se dela urrando como se se vingassem de uma ofensa secular.

Doze homens depois [...] restou no solo, quase sem vida. Nas seguintes horas, ela não foi mais que um corpo, um vulto a mercê dos corvos e dos ratos e, pior que isso, exposto aos olhares maldosos dos raros passantes. Ninguém a ajudou a erguer-se. Vezes sem conta tentou recompor-se, mas, não encontrando forças, voltou a tombar, sem lágrima, sem alma (COUTO, 2009, p. 243-244).

Em Vinte e Zinco (1999) são Jessumina, Margarida e Irene as mulheres que passam a habitar a memória do leitor. Irene, por sua liberdade irreverente, confundida com loucura ou afronta, merece uma menção especial. Recém-vinda de Portugal a Moçambique, para a família, Irene "se desencaminhara, exilada do juízo e das maneiras. Se misturara aos negros, dera licença a rumores e vergonhas. Procedimentos que despergaminhavam a honra familiar. [...] Assim, bela e feliz [...] A moça usufruía do lugar, sem fronteira de medo" (COUTO, 1999, p. 24-25). Miserinha, Admirança, Dulcineusa, Mariavilhosa e Nyembeti vêm de Um rio chamado tempo, uma casa chamada terra (2002) para poetizar um pouco a alma de quem as conhece. Miserinha é de fazer sofrer. Ao falar sobre sua vida faz um breve resumo, "solteira, chorei. Casada, já nem pranto tive. Viúva, a lágrima teve saudade de mim." (COUTO, 2002, p. 133) Entende-se o porquê de tanta lástima quando se toma conhecimento do que fora sua vida, quando o narrador conta um pouco de sua história:

A gorda Miserinha fora casada [...]. Quando o marido dela morreu, vieram familiares que Miserinha nunca tinha visto. Levaram-lhe tudo, os bens, as terras. Até a casa. Ela então ressuscitou esse nome que lhe tinham dado na adolescência: Miserinha. 
Transferiram-na, [...], para um pequeno casebre, de uma só divisão. Ali se deixou ficar, em desleixo de si mesma. Miserinha perdera parcialmente a visão num acidente que ela não sabia reportar. Nem ela nunca confessara essa deficiência. No casebre acabou por esbater ainda mais a visão. [...], dissera que não via cores. Mas a única coisa que a gorda Miserinha via eram sombras. E vozes. (COUTO, 2002, p. 131-132)

Terra sonâmbula (2007), além de Euzinha, com seus olhos inundados de uma tristeza que vem de dentro, a partir das doces memórias que contempla, deixa no ar a ternura pela indiana Assma e por Juliana Bastiana, a velha prostituta cega grata por sua condição, afinal, segundo ela mesma, assim não podia ver o quanto "lá fora, o mundo está pior" (COUTO, 2007, p. 131). A primeira e sua eterna saudade, a segunda e seus amores militares, razão dos infindáveis suspiros. Para dar conta de viver, "Juliana historiava [...] a cega misturava os tempos, fazia do passado um tempo vigente" (COUTO, 2007, p. 132). Sua motivação era guardar as imaginárias cartas que recebia do brigadeiro Silvério Damião, “- Tudo isso são cartas dele, não passa nenhuma semana que não escreva” (COUTO, 2007, p. 132). Quanto a Assma, não se pode esquecer a dor da saudade que culmina num suicídio: se pelas ondas do mar não voltou à sua Índia, talvez pelas labaredas do fogo tenha voltado. Era uma mulher que já não suportava o "peso do mundo. Todo o dia ela ficava na sombria traseira do balcão, cabeça encostada num rádio. Escutava era o quê? Ouvia ruídos, sem sintonia nenhuma. Mas para ela, por trás daqueles barulhos, havia música da sua Índia, melodias de sarar saudades do Oriente" (COUTO, 2007, p. 24). Enquanto, "dos paus de incenso esvoavam fumos. Os olhos de Assma seguiam aqueles perfumes, dançando em tontas direcções. Ela adormecia embalada pelos ruídos" (COUTO, 2007, p. 24). Num gesto de amor a ela, Surendra Valá, seu marido, resolve mandá-la à Índia, sem qualquer recurso,

juntou uns paus e improvisou uma jangada. Assma, a seu lado, canta-encantava qualquer coisa, parecia era um desconcerto de ruídos. Ao fim da tarde, já o indiano tinha completado sua improvisada obra. Deitou a jangada no mar, colocou nela Assma. Foi entrando, ondas adentro e, quando já não pousava o pé no fundo, longamente beijou a esposa na testa. Depois, apontou a jangada numa escolhida direcção e lhe deu um empurrão com força. Ficou acenando uma despedida:

- Vai, Assma! Volta na sua terra! (COUTO, 2007, p. 115-116).

Apesar da boa intenção de Surendra, o mar não a reconhece e devolve Assma ao continente; depois desse dia a mulher passou a viver em cenário de sonho, um cenário indiano que a atraía colocando em sua face sorrisos enigmáticos. Quando do incêndio à casa de Surendra, Assma 
se abandona às chamas e deixa queimar-se tal qual incenso rumo à sua Índia, "ninguém pôde fazer nenhuma coisa..." (COUTO, 2007, p. 120), isso porque contra a vontade de uma mulher ninguém pode fazer coisa alguma - com as mulheres de Mia Couto isso não seria diferente. Do mesmo modo acontece à Luzmina e à Filipa em O outro pé da sereia (2006), aliás, “- Luzmina, não. Sou Santa Luzmina, mãe dos pecadores, padroeira das prostitutas" (COUTO, 2006, p. 75), essa passou a ser a sua autodefinição quando perdera o juízo. Afirmava à família, enfrentando todos os olhares de reprovação, “- Não é para me gabar, mas tenho muito jeito para puta!" (COUTO, 2006, p. 75) A loucura assoma à goesa, outrora crente, que prossegue com diversas heresias, questionando a ação divina e sua utilidade, "Deus, Deus, Deus... Pois se eu fosse Deus, Jesus Cristo não tinha morrido" (COUTO, 2006, p. 76), em seus delírios teimava ter subido "à cruz para descrucificar Cristo" (COUTO, 2006, p. 76) se tendo transformado numa espécie de Nossa Senhora não recompensada por sua devoção e que agora segue apenas "os conselhos do Diabo" (COUTO, 2006, p. 76). Sua espera é por um outro lado, se a felicidade não lhe veio em vida e pelo Bem, há de vir com a morte e pelos braços do Mal. Dona Filipa Caiado compartilha uma desilusão parecida à de Luzmina, não encontra acolhida nos humanos e no que a eles é pertinente - um elefante com toda a sua desproporção a afagava com um carinho nunca antes recebido. Durante a viagem de Goa a Moçambique, a fidalga portuguesa diversas vezes recorre ao animal como fonte de apaziguamento à sua indignação, uma vez que "- Neste barco, não encontro alma mais humana que eu possa tocar” (COUTO, 2006, p. 110). A falta de humanidade, as condições em que os negros são transportados nos porões do navio, o desrespeito às tradições ancestrais são motivos para que Filipa reavalie seus sofrimentos e reveja suas ações em razão de perceber a grandeza do sofrimento alheio. Filipa é um modelo de sensibilidade e de autoconversão.

Os dilemas das mulheres moçambicanas retratadas nos romances convergem em sensações universais, em algum ponto expressam, em menor ou maior proporção, percalços cotidianos de mulheres do mundo todo. Algumas nascidas sob o signo da esperança, outras, não. Para muitas a esperança não é, como se costuma acreditar, a última que morre, porque já nasceram sem acesso a ela. Essas mulheres, porta-bandeiras de diferentes simbologias, traduzem sonhos perdidos, sonhos procurados e sonhos que jamais serão alcançados, tornam as outras mulheres, aquelas que conseguem se desvencilhar das artimanhas de um destino traçado por linhas muita tortas, encarregadas de uma vingança, incumbem-lhes de uma força maior, dotam-nas de armas e de modelos, obrigam-nas a uma tomada de posição e a ações concretas com vistas ao fim das lágrimas que fragilizam as mulheres-feras dominadas por circunstâncias adversas. Essas mulheres sugerem paixão, utopia, e têm nas marcas de suas faces a indicação de caminhos já percorridos, um mapa ao avesso, um mapa a não seguir. Indicam às outras mulheres novas rotas nos espaços vazios de um semblante morti- 
ficado pela vida que lhes trouxe apenas morte ao nascerem, e em diversas situações lembram que a inércia cria vítimas e culpados.

A fibra de tantas mulheres faz o tecido literário de Mia Couto ser de um colorido ímpar, ser de uma sonoridade cansada e digna, de uma maciez rude e simples. Nenhum leitor finaliza uma de suas obras sem que tenha se apaixonado, emocionado ou sofrido com as mulheres. Mulheres do dia a dia, encontráveis em cada alma feminina, encontráveis também em muitos homens que cultivam com suavidade o lado doce da vida.

\section{REFERÊNCIAS BIBLIOGRÁFICAS}

BRANCO, Lúcia C.. O que é escrita feminina. São Paulo: Brasiliense, 1991.

COUTO, Mia. A confissão da leoa. São Paulo: Companhia das Letras, 2012.

. Antes de nascer o mundo. São Paulo: Companhia das Letras, 2009.

. Cronicando. Lisboa: Editorial Caminho, 1991.

. O outro pé da sereia. São Paulo: Companhia das Letras, 2006.

. O último voo do flamingo. São Paulo: Companhia das Letras, 2005.

. Um rio chamado tempo, uma casa chamada terra: romance. Lisboa: Editorial Ndjira, 2002.

. Terra sonâmbula. São Paulo: Companhia das Letras, 2007.

. Vinte e Zinco. Lisboa: Editorial Caminho, 1999.

Recebido para publicação em 18/10/2012

Aprovado em 25/01/2013 